\title{
Identification of the $e$ allele at the Extension locus $(M C 1 R)$ in Brazilian Creole sheep and its role in wool color variation
}

\author{
D. Hepp ${ }^{1}$, G.L. Gonçalves ${ }^{1}$, G.R.P. Moreira ${ }^{2}$, T.R.O. Freitas ${ }^{1}$, \\ C.T.D.C. Martins ${ }^{3}$, T.A. Weimer ${ }^{3}$ and D.T. Passos ${ }^{3}$ \\ ${ }^{1}$ Departamento de Genética, Instituto de Biociências, \\ Universidade Federal do Rio Grande do Sul, Porto Alegre, RS, Brasil \\ ${ }^{2}$ Departamento de Zoologia, Instituto de Biociências, \\ Universidade Federal do Rio Grande do Sul, Porto Alegre, RS, Brasil \\ ${ }^{3}$ Hospital Veterinário, Universidade Luterana do Brasil, Canoas, RS, Brasil \\ Corresponding author: G.R.P. Moreira \\ E-mail: gilson.moreira@ufrgs.br
}

Genet. Mol. Res. 11 (3): 2997-3006 (2012)

Received October 7, 2011

Accepted May 8, 2012

Published May 22, 2012

DOI http://dx.doi.org/10.4238/2012.May.22.5

\begin{abstract}
The melanocortin 1 receptor $(M C 1 R)$ gene has been described as responsible for the black color in some breeds of sheep, but little is known about its function in many colored breeds, particularly those with a wide range of pigmentation phenotypes. The Brazilian Creole is a local breed of sheep from southern Brazil that has a wide variety of wool colors. We examined the $M C 1 R$ gene (Extension locus) to search for the $e$ allele and determine its role in controlling wool color variation in this breed. One hundred and twenty-five animals, covering the most common Creole sheep phenotypes (black, brown, dark gray, light gray, and white), were sequenced to detect the mutations p.M73K and p.D121N. Besides these two mutations, three other synonymous sites $(429,600$, and 725$)$ were found. The dominant allele $\left(E^{D}:\right.$ p. $73 \mathrm{~K}$, and p. $121 \mathrm{~N}$ ) was found only in colored animals, whereas the recessive allele $\left(E^{+}\right.$: p.73M, and p.121D) was homozygous only in white individuals. We
\end{abstract}


concluded that MC1R is involved in the control of wool color in Brazilian Creole sheep, particularly the dark phenotypes, although a second gene may be involved in the expression of the white phenotype in this breed.

Key words: Wool color genetics; Melanin receptors; Native sheep; Southern Brazil

\section{INTRODUCTION}

Coat color is a conspicuous trait in mammals, particularly in domestic species where it is frequently an important attribute for breed recognition. Coat color has practical applications for fiber production in sheep, goats and other farm animals (Fontanesi et al., 2010). Overall, variability in this trait is due to the presence, distribution and activity of the melanocytes that produce two types of pigments, eumelanin and pheomelanin, leading to black/brown and red/ yellow colors, respectively (Searle, 1968).

A large number of genes affecting coat color have been reported in the laboratory mouse (Mus), a model species for pigmentation studies (Bennett and Lamoreux, 2003). In particular, two loci (Agouti and Extension) play a major role in determining coat color, by control and regulation of the relative amounts of eumelanin and pheomelanin in skin and hair (Searle, 1968). The Agouti locus encodes the agouti signaling protein (ASIP; Bultman et al., 1992), a small paracrine signaling molecule that interacts with the product of the Extension locus. This locus encodes for the melanocortin-1 receptor (MC1R), a seven-transmembrane domain G-protein involved in the control of the switch from pheomelanin to eumelanin synthesis in melanocytes. Molecular variants of $M C 1 R$ have been associated with variation in pigmentation in many domesticated mammals, including mice (Robbins et al., 1993), cattle (Klungland et al., 1995; Rouzaud et al., 2000), horses (Marklund et al., 1996), goats (Fontanesi et al., 2009), rabbits (Fontanesi et al., 2006), pigs (Kijas et al., 1998, 2001), and sheep (Våge et al., 2003; Calvo et al., 2006; Royo et al., 2008; Fontanesi et al., 2010). Recently, however, Gonçalves et al. (2012) questioned the importance of this gene in determining the striking coat color variation existing in a rodent lineage.

Particularly in sheep, previous studies have identified two alleles at the Extension locus: the dominant black $\left(E^{D}\right)$ that accounts for the black pigmentation of colored breeds; and the wild type $\left(E^{+}\right)$that is widely distributed in most breeds, in which segregation coupled with Agouti underlies most color variation (Searle, 1968; Sponenberg, 1997). In contrast to mice, the recessive $e$ allele of the Extension locus has not yet been clearly documented in sheep (Fontanesi et al., 2010). However, its role in determining the black and white phenotypes in this domestic species has received much attention in the last 10 years. Våge et al. (1999) investigated the $M C 1 R$ and described two specific mutations (p.M73K and p.D121N) that constitutively activate the dominant allele, characterized as the dominant black extension $\left(E^{D}\right)$, in the Norwegian Dala breed, resulting in black phenotypes. In addition, Norris and Whan (2008) recently characterized the $A S I P$ gene and identified a $190-\mathrm{kb}$ tandem duplication underlying the white coat color of dominant white and tan allele $\left(A^{W t}\right)$. Also, a 5-base pair (bp) deletion in the exon 2, and an amino acid replacement in the exon 4, as well as a regulatory mutation, were associated with the black recessive non-agouti $\left(A^{a}\right)$ allele (Gratten et al., 2010; Norris and Whan, 2008; Royo et al., 2008). The occurrence of both alleles $A^{a}(A S I P)$ and $E^{D}(M C 1 R)$ has been proposed for breeds with black phenotypes (Roberts and White, 1930), and was particu- 
larly demonstrated in the Masesse sheep breed (Fontanesi et al., 2011).

However, in a few colored breeds of sheep, e.g., Aragonesa, Salz, Norwegian Pelt, Nanping black-boned, Romney Marsh black-boned, and Xalda, the dominant $E^{D}$ MCIR allele that accounts for the black phenotype has not been found (Våge et al., 2003; Royo et al., 2008; Deng et al., 2009). Furthermore, its presence has not been investigated in various breeds, in which a wide range of wool colors can be found in addition to the extreme black and white phenotypes, for example, the Creole. This native breed of sheep is officially recognized in Brazil, having descended from the first animals brought to South America by European colonists in the 17th century (Henkes et al., 1993; Vaz, 2000). They were introduced by the Jesuits into Rio Grande do Sul, the southernmost state of Brazil, where they have been reared continuously for four centuries. The extant flocks show a remarkable variety of wool colors ranging from black to white, including several intermediate hues of gray and brown (Gonçalves et al., 2010; Moreira GRP, unpublished results). Despite this conspicuous diversity, there is no information about the inheritance of these colors and the genetic mechanisms involved in the regulation of their wool pigmentation. Therefore, in this study, we characterized the MC1R coding region in different pigmentation phenotypes of the Creole sheep, to investigate the presence of the Extension allele. We also infer the putative role of other substitutions in this gene controlling the wool color in this phenotypically diverse breed.

\section{MATERIAL AND METHODS}

\section{Animals and samples}

A total of 125 blood samples were collected from adults of five purebred flocks belonging to members of the Brazilian Association of Creole Sheep Breeders (ABCOC) and that are under the genealogical control of ARCO (National Association of Brazilian Sheep Breeders): Buriti $(N=45)$, Esmeralda $(N=11)$, Harmonia $(N=9)$, Santa Fé $(N=55)$, and Sobrado Branco $(\mathrm{N}=5)$. The wool color was evaluated on digital images taken from a dorsal view with a Sony ${ }^{\circledR}$ Cyber-shot DSC-H10 camera, and classified by using a RGB color table (Walsh KJ, 2007. Copy at http://web.njit.edu/ walsh/rgb.html). The specimens analyzed covered the five main color phenotypes described in the Creole sheep: black (from black to gray 10), brown (from tan 02 to tan 04), dark gray (from gray 40 to gray 60), light gray (from gray 70 to gray 80), and white (Figure 1). For statistical purposes, these were categorized into two classes: Colored and White. Colored individuals were subdivided into two classes: Black and Nonblack, the latter being further subdivided into Brown, Dark gray, and Light gray.

\section{DNA extraction and sequencing}

Genomic DNA was isolated according to procedures described by Miller et al. (1988). The entire coding region ( $954 \mathrm{bp}$ ) and a small portion of flanking regions of $M C 1 R$ were sequenced in 74 individuals, including all color phenotypes, to confirm the presence of the SNPs and to investigate other substitutions potentially involved in color diversity and variation in $M C 1 R$ non-transcript regions. Primers for MC1R amplification and sequencing (Table 1) were obtained from Våge et al. (1999). PCR was performed using a PT-100 thermal cycler (MJ Research, USA) in a volume of $20 \mu \mathrm{L}$ containing 10-100 ng DNA template, 1 U Taq DNA poly- 
merase (Invitrogen), 1X PCR buffer, $2.5 \mathrm{mM}$ dNTPs, 10 pmol of each primer and optimized $\mathrm{MgCl}_{2}$ concentration (from 1.0 to $2.0 \mathrm{mM}$ ). The PCR profile was as follows: $5 \mathrm{~min}$ at $95^{\circ} \mathrm{C}$; 35 amplification cycles of $30 \mathrm{~s}$ at $95^{\circ} \mathrm{C}, 30 \mathrm{~s}$ at the appropriate annealing temperature (Table 1), $30 \mathrm{~s}$ at $72^{\circ} \mathrm{C}$, and $5 \mathrm{~min}$ at $72^{\circ} \mathrm{C}$. For sequencing of the $M C 1 R$ fragments, $3-5 \mu \mathrm{L}$ PCR product were treated with $2 \mu \mathrm{L}$ ExoSAP (USB Corporation, USA) following the manufacturer protocol. Cycle sequencing of the PCR products was carried out with the Big Dye v3.1 kit (Applied Biosystems, USA). Sequencing reactions were loaded on an ABI3730XL sequencer (Applied Biosystems) after cleaning steps performed with $73.5 \mu \mathrm{L} 70 \%$ ethanol, and $1.5 \mu \mathrm{L} 50$ $\mathrm{mM} \mathrm{MgCl}$. All sequences were visually inspected, edited, assembled, and aligned using the CodonCode Aligner software. Nomenclature of the single nucleotide polymorphisms (SNPs) detected was obtained following the Nomenclature for the description of sequence variation (Copy at http://www.hgvs.org/mutnomen/). Sequences were deposited in the GenBank database under the accession Nos. JF279452-JF279466.
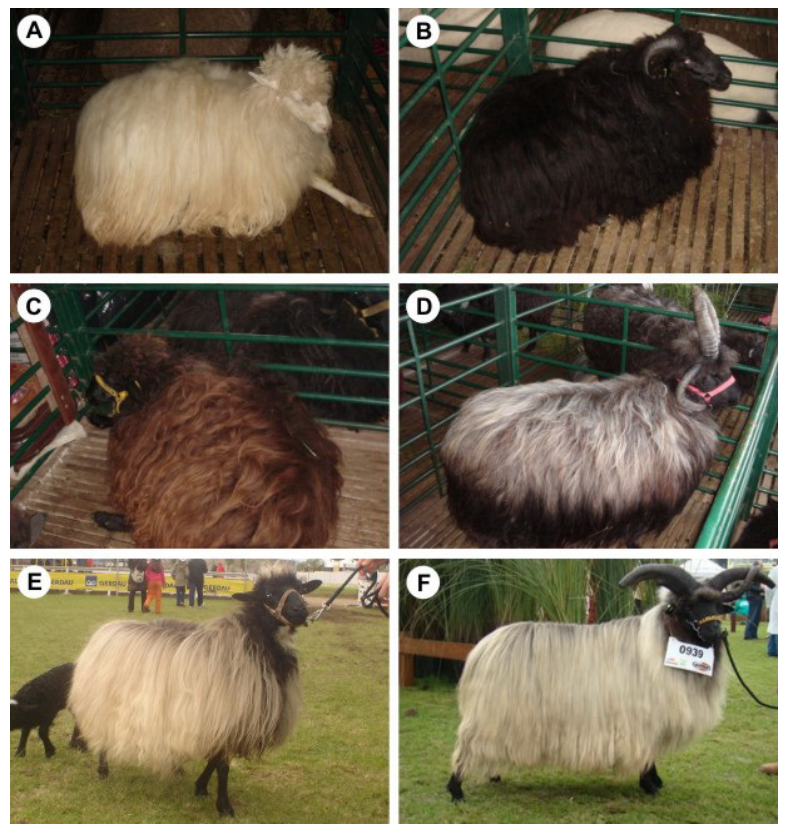

Figure 1. Wool color variation in in the Brazilian Creole sheep. A. White. B. Black. C. Brown. D. Dark gray. E. and $\mathbf{F}$. Light gray.

\section{Genotyping}

We genotyped two non-synonymous mutations by PCR-RFLP: c.218T >A, p.M73K; and c. $361 \mathrm{G}>\mathrm{A}, \mathrm{p} . \mathrm{D} 121 \mathrm{~N}$, which cause the $E^{D}$ allele, in all samples of Creole sheep. PCR amplification was carried out with primer pairs used for sequencing parts of the $M C 1 R$ gene (Table 1). The amplification reaction was composed of $1.5 \mathrm{mM} \mathrm{MgCl}, 200 \mu \mathrm{M}$ of each dNTP, $0.2 \mu \mathrm{M}$ of each primer, $50-80 \mathrm{ng}$ genomic DNA, and $0.5 \mathrm{U}$ Taq DNA polymerase in a final volume of $25 \mu \mathrm{L}$. The thermal cycling conditions were $94^{\circ} \mathrm{C}$ for 3 min and 35 cycles of $94^{\circ} \mathrm{C}$ 
for $1 \mathrm{~min}$, annealing temperature between $59^{\circ}$ and $65^{\circ} \mathrm{C}$ (Table 1 ) for $1 \mathrm{~min}$, and $72^{\circ} \mathrm{C}$ for 1 min, with a final extension step of $72^{\circ} \mathrm{C}$ for $5 \mathrm{~min}$. The PCR product of primers E3F/E6R and $\mathrm{E} 3 \mathrm{~F} / \mathrm{E} 8 \mathrm{R}(5 \mu \mathrm{L})$ was digested in a $20 \mu \mathrm{L}$ reaction volume with $1 \mathrm{X}$ reaction buffer and $5 \mathrm{U}$ of the enzymes NlaIII and MseI, respectively. These products were electrophoresed in $10 \%$ polyacryamide:bisacrylamide 29:1 1X TBE gels. DNA fragments were visualized by ethidium bromide gel staining. Allele c.218A was characterized by four DNA fragments $(145+90+48$ $+27 \mathrm{bp})$, whereas allele c. $218 \mathrm{~T}$ consisted of five DNA fragments $(118+90+48+27+17 \mathrm{bp})$. The analysis of the c.361G $>$ A mutation was obtained by digesting a 366-bp amplified MC1R gene region, and the resulting pattern was characterized by one fragment of 754 bp (allele c.361G) or two fragments of $496+258$ bp (allele c.361A).

Table 1. Primer pairs used for PCR-RFLP of the SNPs and sequencing of the $M C 1 R$ gene (Våge et al., 1999),
using the Bos taurus (NM174108) sequence as reference.
\begin{tabular}{llcccl}
\hline Primer pair & Primer sequence $\left(5^{\prime} \rightarrow 3^{\prime}\right)$ & Tm $\left({ }^{\circ} \mathrm{C}\right)$ & Product length (bp) & Region & Reaction \\
\hline 1 & $\begin{array}{l}\text { E3F: GTGCCTGGAGGTGTCCATC } \\
\text { E6R: AAGCAGAGGCTGGACACCAT }\end{array}$ & 60 & 300 & $102-401$ & PCR-RFLP/SNP c.218T>A \\
2 & $\begin{array}{l}\text { E3F: GTGCCTGGAGGTGTCATC } \\
\text { E8R: GGCCAGGAAGAGGTGAAG } \\
3\end{array}$ & 59 & 754 & $102-855$ & PCR-RFLP/SNP c.361G $>$ A \\
E1F: CATGCCTGGGCCGACATTTGT & 65 & 1160 & $(-) 117-1043$ & Sequencing \\
\hline
\end{tabular}

$\mathrm{F}=$ forward primer; $\mathrm{R}=$ reverse primer; $\mathrm{Tm}=$ annealing temperature .

\section{Data analysis}

Sequencing results were used to generate haplotypes including the previously identified SNPs within the sheep MC1R gene, inferred using the software DnaSP v5 (Librado and Rozas, 2009). We calculated overall haplotype and nucleotide diversity, as well as the haplotype frequency in each phenotype. Hardy-Weinberg equilibrium for allele frequencies was examined by the chi-square test using the MAXLIK program (Reed and Schull, 1968). The associations between allele frequencies/genotypes and wool color were also evaluated by chisquare tests (alpha $=0.05)$, using the SPSS ${ }^{\circledR}$ v10.0.5 software.

\section{RESULTS}

\section{$M C 1 R$ sequence characterization}

The sequencing of $1045 \mathrm{bp}$ of the MC1R gene (including the entire coding region of $954 \mathrm{bp}, 35 \mathrm{bp}$ of the 5'-UTR, and $58 \mathrm{bp}$ of the 3'-UTR) in Creole sheep with different wool colors revealed $5 \mathrm{SNPs}$, including the $e$ allele previously observed in the ovine Extension locus (Figure 2). Most of the colored phenotypes showed the c.218T $>\mathrm{A}$ and the c.361G $>\mathrm{A}$ substitutions, causing the p.M73K and the p.D121N amino acid changes of the $E^{D}$ allele. However, the white individuals showed only the wild type allele $\left(E^{+}\right)$(Figure 3$)$. The other three polymorphisms (c.429C $>\mathrm{T}$; c.600T $>\mathrm{G}$; c. $735 \mathrm{C}>\mathrm{T}$ ) were synonymous substitutions. These three SNPs and the two non-synonymous mutations of the $E^{D}$ allele identified resulted in seven haplotypes (Table 2). Haplotype 1 (H1) represents the wild type $M C 1 R$ sequence, and was observed in white and black phenotypes. Haplotype 2 (H2) differs from $\mathrm{H} 1$ in the presence of the 
c. $218 \mathrm{~A}$, c.361 A and c. $429 \mathrm{C}$ alleles, and occurred in brown and black individuals. Haplotype 3 (H3) differs by 4 polymorphic sites (c.218, c.361, c.429, and c.600) from $\mathrm{H} 2$ and was observed in brown and light-gray phenotypes. Haplotype 4 (H4) differs from H3 by the two nonsynonymous substitutions of the $E^{D}$ allele and the three synonymous sites, and was present in all except white individuals, representing the mutant haplotype. Haplotype 5 (H5) differs from the H3 only by the polymorphism $\mathrm{G}$ at site c.429, and occurred only in brown phenotypes. Haplotype 6 (H6) differs from the H2 only by three nucleotide sites $(218,361$, and 735 ), and was found in only black individuals. Finally, haplotype 7 (H7) differs from most others in at least two sites, which were in heterozygosis, and was present only in the dark-gray phenotype. The haplotype diversity was $0.85 \pm 0.05$ (= mean \pm standard error) and the nucleotide diversity 0.002. No difference was found in the small segments of the 5'-and 3'-UTR regions sequenced.
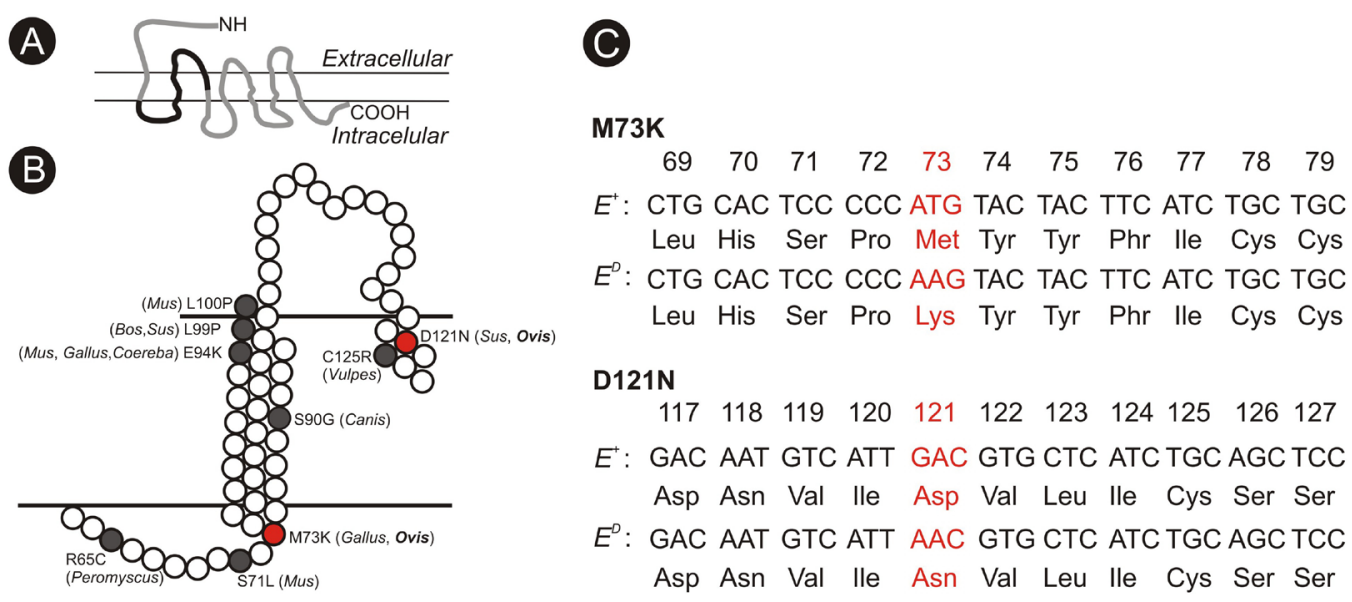

Figure 2. Schematic representation of the $M C 1 R$ gene. A. Two-dimensional protein structure, with transmembrane region indicated by enlarged black area. B. Mutations in the $M C 1 R$ gene as described by Majerus and Mundy (2003). C. Identification of the two specific mutations (allele $e$ ) in the MC1R gene for the Creole sheep, showing the Met ${ }^{73}$ Lys (M73K), and the Asp ${ }^{121}$ Asn changes (D121N).

A

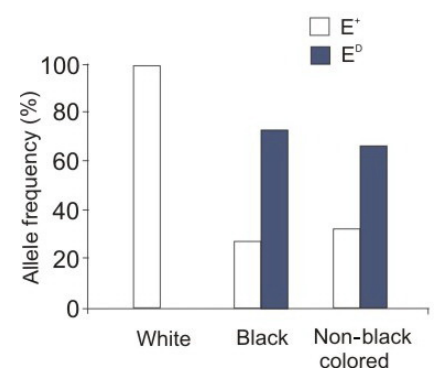

(B)

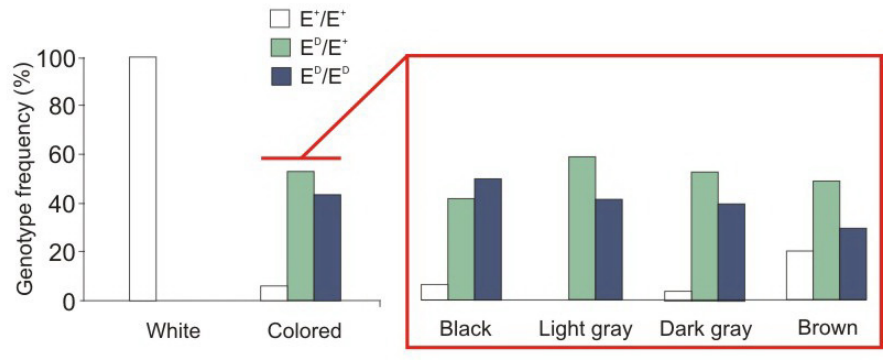

Figure 3. Allele (A) and genotype (B) frequencies (\%) of the $M C 1 R$ gene in the Creole sheep. Genotype frequencies within colored individuals are depicted for each color within the red rectangle. $E^{+}=$Recessive allele; $E^{D}=$ dominant allele. 
Table 2. Haplotype diversity observed in Creole sheep MC1R coding region sequences.

\begin{tabular}{|c|c|c|c|c|c|c|c|c|c|c|}
\hline \multirow{2}{*}{$\begin{array}{l}\text { Haplotype } \\
\text { No. }\end{array}$} & \multicolumn{5}{|c|}{ Nucleotide site } & \multicolumn{5}{|c|}{ Phenotype } \\
\hline & 218 & 361 & 429 & 600 & 735 & White & Brown & Light gray & Dark gray & Black \\
\hline H1 & $\mathrm{T}$ & G & $\mathrm{T}$ & G & $\mathrm{T}$ & 2 & & & & 1 \\
\hline $\mathrm{H} 2$ & A & A & $\mathrm{C}$ & G & $\mathrm{T}$ & & 1 & & & 1 \\
\hline H3 & $\mathrm{T}$ & G & $\mathrm{T}$ & $\mathrm{T}$ & $\mathrm{T}$ & & 1 & 1 & & \\
\hline $\mathrm{H} 4$ & A & A & $\mathrm{T}$ & G & $\mathrm{T}$ & & 2 & 1 & 1 & 2 \\
\hline H5 & $\mathrm{T}$ & G & $\mathrm{C}$ & $\mathrm{T}$ & $\mathrm{T}$ & & 2 & & & \\
\hline H6 & $\mathrm{T}$ & G & $\mathrm{C}$ & G & $\mathrm{C}$ & & & & & 2 \\
\hline H7 & A & A & C & G & $\mathrm{C}$ & & & & 1 & \\
\hline Total & & & & & & 2 & 6 & 2 & 2 & 6 \\
\hline
\end{tabular}

\section{Allele and genotype frequencies associated with wool color}

Allele frequencies were in Hardy-Weinberg equilibrium in the Black $\left(\chi^{2}=0.778\right.$, d.f. $=1$, $\mathrm{P}$ $=0.378)$, Non-Black colored $\left(\chi^{2}=3.29\right.$, d.f. $\left.=1, \mathrm{P}<0.070\right)$ and Colored $(=$ Black + Non-Black $)\left(\chi^{2}\right.$ $=3.19$, d.f. $=1, \mathrm{P}=0.075)$ groups. They varied between White, Black and Non-Black colored individuals $\left(\chi^{2}=65.26\right.$, d.f. $=4, \mathrm{P}<0.001$; Figure $\left.3 \mathrm{~A}\right)$. Absolute values of the corresponding residuals were 8.04, 2.54 and 3.98, for White, Black and Non-Black, respectively. Thus, the frequency of allele $E^{+}$(equal to $100 \%$ ) was significantly greater within the White group, and those of allele $E^{D}$, in the Black and Non-Black colored groups. Genotype frequencies varied significantly between the White and Colored groups $\left(\chi^{2}=86.42\right.$, d.f. $=4, \mathrm{P}<0.001$; Figure $\left.3 \mathrm{~B}\right)$. Absolute values of the corresponding residuals were: 9.30 for the $E^{+} / E^{+}$genotype in the White individuals, 4.26 for $E^{D /}$ $E^{+}$and 3.60 for $E^{D} / E^{D}$ in the Colored ones. Thus, the frequency of genotype $E^{+} / E^{+}$(equal to $100 \%$ ) was significantly greater within the White group, and those of genotypes $E^{+} / E^{D}$ and $E^{D} / E^{D}$ in the Colored one. There was no difference in genotype frequency between the Black, Light gray, Dark gray and Brown subgroups $\left(\chi^{2}=6.38\right.$, d.f. $=6, \mathrm{P}=0.382$; shown in the red rectangle in Figure $\left.3 \mathrm{~B}\right)$.

\section{DISCUSSION}

Previous studies identified two alleles at the Extension locus in sheep: $E^{D}$ and $E^{+}$ (Searle, 1968; Sponenberg, 1997). Allele $E^{D}$, which was subsequently characterized at the molecular level (Våge et al., 1999), is directly involved in sheep pigmentation (Lundie, 2004). Our data indicated that this allele is also clearly responsible for the wool color variation in Creole sheep, particularly determining the black phenotypes. The results for genotype frequency support this influence of the $M C 1 R$; all white individuals were homozygous for $E^{+}$and only colored ones showed the dominant allele $E^{D}$, suggesting that this inhibits the expression of the white phenotype. A few colored individuals did not show the $E^{D}$ allele, and other nonsynonymous mutations were not found in $M C 1 R$. Together, these results indicate that other genes must be involved in the control of coat color in this breed. We found five SNPs and seven haplotypes in the MC1R sequence for the Creole sheep. All these SNPs have been identified in other breeds (Table 3). Mostly, they have been demonstrated in European and Asian breeds, with relatively narrow variation in wool color. This is the first study of these SNPs in a South American native breed of sheep with wide variation in fleece color. Our identification of different polymorphic sites, with high haplotype and nucleotide diversity in a native breed, increases our knowledge of variation in the ovine $M C 1 R$ loci. 
Table 3. SNPs identified for the MC1R in the domestic sheep (Ovis aries).

\begin{tabular}{|c|c|c|c|c|}
\hline SNP & Present & $\begin{array}{l}\text { Amino acid } \\
\text { change }\end{array}$ & Breed & Reference \\
\hline$-31 \mathrm{G} \rightarrow \mathrm{A}$ & Yes & $\begin{array}{c}\text { None } \\
\left(5^{\prime}-\text {-UTR }\right)\end{array}$ & $\begin{array}{l}\text { Apennine, Bergamasca, Comisana, Cornigliese-like, } \\
\text { DelleLanghe, Merinizzata Italiana, Sardinian, Valle Del Belice }\end{array}$ & Fontanesi et al. (2010) \\
\hline $12 \mathrm{~A} \rightarrow \mathrm{G}$ & Yes & Synonymous & Nanping black-boned & Deng et al. (2009) \\
\hline $144 \mathrm{G} \rightarrow \mathrm{C}$ & Yes & Synonymous & Romney Marsh black-boned & Deng et al. (2009) \\
\hline $199 \mathrm{C} \rightarrow \mathrm{T}$ & Yes & $\operatorname{Arg}^{67} \mathrm{Cys}$ & Valle del Belice & Fontanesi et al. (2010) \\
\hline \multirow[t]{9}{*}{$218 \mathrm{~T} \rightarrow \mathrm{A}$} & Yes & $\mathrm{Met}^{73}$ Lys & Norwegian Dala & Våge et al. (1999) \\
\hline & & & Damara, Black Merino, Black Corriedale & Våge et al. (2003) \\
\hline & & & Manchega & Calvo et al. (2006) \\
\hline & & & Black Castellana, Karakul & Royo et al. (2008) \\
\hline & & & Massese, Valle del Belice & Fontanesi et al. (2010) \\
\hline & & & Creole & This study \\
\hline & No & & Aragonesa, Salz, Norwegian Pelt & Våge et al. (2003) \\
\hline & & & Nanping black-boned, Romney Marsh black-boned & Deng et al. (2009) \\
\hline & & & Xalda & Royo et al. (2008) \\
\hline \multirow[t]{9}{*}{$361 \mathrm{G} \rightarrow \mathrm{A}$} & Yes & $\mathrm{Asp}^{121} \mathrm{Asn}$ & Norwegian Dala & Våge et al. (1999) \\
\hline & & & Damara, Black Merino, Black Corriedale & Våge et al. (2003) \\
\hline & & & Manchega & Calvo et al. (2006) \\
\hline & & & Black Castellana, Karakul & Royo et al. (2008) \\
\hline & & & Massese, Valle del Belice & Fontanesi et al. (2010) \\
\hline & & & Creole & This study \\
\hline & No & & Aragonesa, Salz, Norwegian Pelt & Våge et al. (2003) \\
\hline & & & Nanping black-boned, Romney Marsh black-boned & Deng et al. (2009) \\
\hline & & & Xalda & Royo et al. (2008) \\
\hline $429 \mathrm{C} \rightarrow \mathrm{T}$ & Yes & Synonymous & Apennine, Bergamasca, Comisana, Cornigliese-like, & Fontanesi et al. (2010) \\
\hline $\begin{array}{l}600 \mathrm{~T} \rightarrow \mathrm{G} \\
735 \mathrm{~T} \rightarrow \mathrm{C}\end{array}$ & & & $\begin{array}{l}\text { Delle Langhe, Merinizzata Italiana, Sardinian, Valle del Belice } \\
\text { Creole }\end{array}$ & This study \\
\hline
\end{tabular}

The Creole sheep originated from the flocks brought to South America in the 17th century (Henkes et al., 1993; Vaz, 2000) and, unlike other breeds, has not been selected for a specific color. The diversity of colors observed in this breed could be the result of the action of different genes involved in the synthesis and/or transport of melanin, such as ASIP, TYRP and $O C T$, which remains to be tested. The differences observed here between white and colored $E^{+}$ homozygous individuals could be due to the presence of the dominant white $A S I P$ allele $\left(A^{W t}\right)$ in the white individuals, whereas the colored sheep were homozygous for a recessive $A S I P$ allele (either $A^{a}$ or other $A S I P$ alleles), which should be further explored. The MCIR and $A S I P$ genes show epistatic interactions. The $M C 1 R$ dominant allele $E^{D}$ usually inhibits the expression of $A S I P$ alleles. Thus, only in the $E^{+}$homozygous individuals will the expression of the different $A S I P$ alleles be observed (Voisey and van Daal, 2002).

Two main varieties, Frontier and Highlander, have been recognized for the Creole sheep. Conspicuous morphological traits, in addition to pigmentation, differentiate these varieties. The body size of the Highlander is larger, and it is covered with black, shorter fleece (Vaz, 2000). The Frontier is smaller and shows a wide range of pigmentation phenotypes (light and dark gray, brown and white), as well as longer fleece. Gonçalves et al. (2010) demonstrated, based on microsatellites and mitochondrial markers, that these varieties are genetically different, and suggested that the black color may have been fixed in the Highlander type. Another particular aspect in Creole sheep coloration is the continuous variation in the coloration pattern, including several hues of gray and pale phenotypes found in the Frontier variety. In cattle, several breeds carrying the $e$ allele show a wide range of redness/paleness (from brown to white) (Klungland et al., 1995; Rouzaud et al., 2000; Maudet and Taberlet, 2002; Russo et 
al., 2007). The $A^{W t}$ allele has been suggested to determine, at least in part, the white pheomelanic coat color (Sponenberg, 1997). The molecular basis of the $A^{W t}$ allele has recently been determined by Norris and Whan (2008), who identified a copy number variation affecting the $A S I P, A H C Y$, and ITCH genes. However, it seems evident that other loci (e.g., KIT) are involved in determining white coat color in sheep (Renieri et al., 2008).

Our findings are also important from a conservation-genetics perspective, because of two major aspects of current management practices of Creole sheep varieties. First, crossbreeding between the Frontier and Highlander types is a common ongoing practice. By this crossbreeding, farmers intend to concomitantly increase the body and fleece sizes of their sheep. In other words, they expect to combine in a single flock the larger body size of the Highlander and the larger fleece size of the Frontier, thus enhancing both meat and wool production. We demonstrated that the black color is strongly influenced by the MC1R dominant allele. Thus, by using rams of this type in a Frontier flock, most offspring will likely be black and probably larger, reducing the frequency of white sheep, traditionally related to the Frontier phenotype in the Creole breed. As a consequence, we predict that the characteristics of the Frontier, whose flocks are naturally smaller in number (Vaz, 2000) and less genetically diverse (Gonçalves et al., 2010), may be progressively absorbed by crossbreeding.

In summary, our data demonstrated the influence of the MC1R gene in controlling wool coloration in Creole sheep, particularly related to the black phenotype, and that at least a second locus is involved in producing the white phenotype segregation in this breed. Together, these results have a direct relationship to conservation efforts to preserve their diversity in color. We emphasize that the remarkable diversity in wool colors among Creole sheep highlights the necessity to preserve this livestock resource as it currently exists, by maintaining the random breeding that has been acting on this native breed for the last 400 years.

\section{ACKNOWLEDGMENTS}

Research supported by CNPq grants awarded to T.R.O. Freitas, G.L. Gonçalves, G.R.P. Moreira, and T.A. Weimer. Thanks are due to the members of the ABCOC (Brazilian Association of Creole Sheep Breeders) for kindly providing their sheep to be sampled. Denis S. Silva (UFRGS) helped edit the figures. We acknowledge Sidia M. Callegaris-Jacques (UFRGS) for her support in the statistical analysis. We are also grateful to Janet W. Reid for editing the text.

\section{REFERENCES}

Bennett DC and Lamoreux ML (2003). The color loci of mice-a genetic century. Pigment Cell Res. 16: 333-344.

Bultman SJ, Michaud EJ and Woychik RP (1992). Molecular characterization of the mouse agouti locus. Cell 71: 11951204.

Calvo J, Bouzada J, Jurado J and Serrano M (2006). Genetic substructure of the Spanish Manchega sheep breed. Small Rumin. Res. 64: 116-125.

Deng WD, Shu W, Yang SL, Shi XW, et al. (2009). Pigmentation in black-boned sheep (Ovis aries): association with polymorphism of the MC1R gene. Mol. Biol. Rep. 36: 431-436.

Fontanesi L, Tazzoli M, Beretti F and Russo V (2006). Mutations in the melanocortin 1 receptor (MC1R) gene are associated with coat colours in the domestic rabbit (Oryctolagus cuniculus). Anim. Genet. 37: 489-493.

Fontanesi L, Beretti F, Riggio V, Dall'Olio S, et al. (2009). Missense and nonsense mutations in melanocortin 1 receptor $(M C 1 R)$ gene of different goat breeds: association with red and black coat colour phenotypes but with unexpected evidences. BMC Genet. 10: 47.

Fontanesi L, Beretti F, Riggio V, Dall'Olio S, et al. (2010). Sequence characterization of the melanocortin 1 receptor 
$(M C 1 R)$ gene in sheep with different coat colours and identification of the putative e allele at the ovine extension locus. Small Rumin. Res. 91: 200-207.

Fontanesi L, Dall'Olio S, Beretti F, Portolano B, et al. (2011). Coat colours in the Massese sheep breed are associated with mutations in the agouti signalling protein $(A S I P)$ and melanocortin 1 receptor $(M C 1 R)$ genes. Animal 5: 8-17.

Gonçalves GL, Moreira GR, Freitas TR, Hepp D, et al. (2010). Mitochondrial and nuclear DNA analyses reveal population differentiation in Brazilian Creole sheep. Anim. Genet. 41: 308-310.

Gonçalves GL, Hoekstra HE and Freitas TRO (2012). Striking coat colour variation in tuco-tucos (Rodentia: Ctenomyidae): a role for the melanocortin-1 receptor? Biol. J. Linn. Soc. 105: 665-680.

Gratten J, Pilkington JG, Brown EA, Beraldi D, et al. (2010). The genetic basis of recessive self-colour pattern in a wild sheep population. Heredity 104: 206-214.

Henkes LE, Weimer TA, Franco MHLP and Moraes JCF (1993). Genetic characterization of the "Crioula lanada" sheep from southern Brazil. Rev. Bras. Genet. 16: 449-455.

Kijas JM, Wales R, Tornsten A, Chardon P, et al. (1998). Melanocortin receptor 1 (MC1R) mutations and coat color in pigs. Genetics 150: 1177-1185.

Kijas JM, Moller M, Plastow G and Andersson L (2001). A frameshift mutation in MC1R and a high frequency of somatic reversions cause black spotting in pigs. Genetics 158: 779-785.

Klungland H, Vage DI, Gomez-Raya L, Adalsteinsson S, et al. (1995). The role of melanocyte-stimulating hormone (MSH) receptor in bovine coat color determination. Mamm. Genome 6: 636-639.

Librado P and Rozas J (2009). DnaSP v5: A software for comprehensive analysis of DNA polymorphism data. Bioinformatics 25: 1451-1452.

Lundie R (2004). The Genetics of Colour in Sheep - Some Basics. In: The World of Coloured Sheep (Lundie RS and Wilkinson EJ, eds.). The Black and Coloured Sheep Breeder's Association of New Zealand, Timaru, 111-122.

Majerus ME and Mundy NI (2003). Mammalian melanism: natural selection in black and white. Trends Genet. 19: 585-588.

Marklund L, Moller MJ, Sandberg K and Andersson L (1996). A missense mutation in the gene for melanocyte-stimulating hormone receptor $(M C 1 R)$ is associated with the chestnut coat color in horses. Mamm. Genome 7: 895-899.

Maudet $\mathrm{C}$ and Taberlet $\mathrm{P}$ (2002). Holstein's milk detection in cheeses inferred from melanocortin receptor 1 (MC1R) gene polymorphism. J. Dairy Sci. 85: 707-715.

Miller SA, Dykes DD and Polesky HF (1988). A simple salting out procedure for extracting DNA from human nucleated cells. Nucleic Acids Res. 16: 1215.

Norris BJ and Whan VA (2008). A gene duplication affecting expression of the ovine ASIP gene is responsible for white and black sheep. Genome Res. 18: 1282-1293.

Reed TE and Schull WJ (1968). A general maximum likelihood estimation program. Am. J. Hum. Genet. 20: 579-580.

Renieri C, Valbonesi A, La Manna V, Antonini M, et al. (2008). Inheritance of coat colour in Merino sheep. Small Rumin. Res. 74: 23-29.

Robbins LS, Nadeau JH, Johnson KR, Kelly MA, et al. (1993). Pigmentation phenotypes of variant extension locus alleles result from point mutations that alter MSH receptor function. Cell 72: 827-834.

Roberts JAF and White RG (1930). Colour inheritance in sheep. IV. White colour, recessive black colour, recessive brown colour, badger-face pattern and reverse badger-face pattern. J. Genet. 22: 165-180.

Rouzaud F, Martin J, Gallet PF, Delourme D, et al. (2000). A first genotyping assay of French cattle breeds based on a new allele of the extension gene encoding the melanocortin-1 receptor (Mc1r). Genet. Sel. Evol. 32: 511-520.

Royo LJ, Alvarez I, Arranz JJ, Fernandez I, et al. (2008). Differences in the expression of the ASIP gene are involved in the recessive black coat colour pattern in sheep: evidence from the rare Xalda sheep breed. Anim. Genet. 39: 290-293.

Russo V, Fontanesi L, Scotti E, Tazzoli M, et al. (2007). Analysis of melanocortin 1 receptor (MC1R) gene polymorphisms in some cattle breeds: their usefulness and application for the breed traceability and authentication of Parmigiano Reggiano cheese. Ital. J. Anim. Sci. 6: 257-272.

Searle AG (1968). Comparative Genetics of Coat Colour in Mammals. Logos Press, London.

Sponenberg DP (1997). Genetics of Colour and Hair Texture. In: The Genetics of Sheep (Piper L and Ruvinsky A, eds.). CAB International, New York, 51-86.

Våge DI, Klungland H, Lu D and Cone RD (1999). Molecular and pharmacological characterization of dominant black coat color in sheep. Mamm. Genome 10: 39-43.

Våge DI, Fleet MR, Ponz R, Olsen RT, et al. (2003). Mapping and characterization of the dominant black colour locus in sheep. Pigment. Cell Res. 16: 693-697.

Vaz CMSL (2000). Morfologia e Aptidão da Ovelha Crioula Lanada. EMBRAPA Pecuária Sul, Bagé.

Voisey J and van Daal A (2002). Agouti: from mouse to man, from skin to fat. Pigment Cell Res. 15: 10-18. 